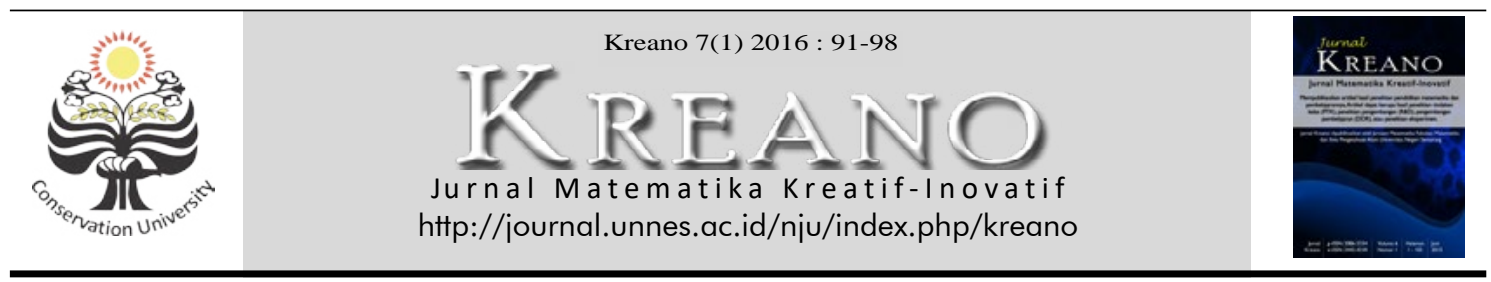

\title{
Peningkatan Aktivitas dan Hasil Belajar Matematika dengan Metode Tutor Sebaya pada Siswa Kelas X IPA 7 Materi Trigonometri SMA Negeri 1 Kudus
}

\author{
Teguh Prasojo',
}

'Guru Matematika SMA 1 Kudus, Indonesia

Coresponding Author Email: teg_pras94@yahoo.com

DOI: http://dx.doi.org/10.15294/kreano.v7i1.5049

Received : January 2016; Accepted: March 2016; Published: June 2016

\begin{abstract}
Abstrak
Tujuan dari penelitian ini adalah untuk meningkatkan aktivitas dan hasil belajar siswa materi trigonometri melalui pembelajaran matematika dengan metode Tutor Sebaya pada siswa kelas X IPA 7 SMA 1 Kudus tahun pelajaran 2012/2013. Penelitian ini merupakan penelitian tindakan kelas yang dilakukan dalam 2 siklus yang masing-masing terdiri 4 tahap yaitu perencanaan, pelaksanaan tindakan, observasi, dan refleksi. Hasil pengamatan untuk keaktifan siswa ada peningkatan sebesar $15,14 \%$. Hasil belajar matematika dari kondisi awal ke siklus I meningkat sebesar $14,42 \%$, sedangkan dari siklus I ke siklus II ada peningkatan sebesar $7,69 \%$, sehingga secara keseluruhan dari kondisi awal ke siklus II ada peningkatan sebesar 23,22\%. Jadi dapat disimpulkan bahwa dengan menggunakan metode tutor sebaya dapat meningkatkan aktivitas dan hasil belajar siswa kelas X IPA 7 SMA 1 Kudus tahun pelajaran 2012/2013 pada materi trigonometri.
\end{abstract}

\begin{abstract}
The purpose of this research is to improve the activity and student learning outcomes through learning mathematics trigonometry materials with methods Peer tutoring in class XIPA 7 SMA 1 Kudus in the academic year 2012/2013. This research is a classroom action research conducted in two cycles, each of which comprises four stages: planning, action, observation, and reflection. The observation of student activity there is an increase of $15.14 \%$. Mathematics learning outcomes from the initial conditions to the first cycle increased by $14.42 \%$, while from the first cycle to the second cycle there is an increase of 7.69\%, so that the whole of the first condition to the second cycle there is an increase of $23.22 \%$. So it can be concluded that by using the method of peer tutors can increase the activity and results of class $X$ student IPA 7 SMA 1 Kudus in the academic year 2012/2013 in the subject of trigonometry.
\end{abstract}

Keywords: activities; learning outcomes; peer tutoring methods; trigonometry

\section{PENDAHULUAN}

Dalam proses belajar mengajar di sekolah, aktivitas siswa merupakan hal yang sangat penting dan perlu diperhatikan oleh guru sehingga proses belajar yang ditempuh benarbenar akan memperoleh hasil yang optimal. Dalam belajar diperlukan aktivitas karena pada prinsipnya belajar adalah berbuat dan bertingkah laku (learning by doing), jadi belajar adalah melakukan kegiatan. Tidak ada belajar apabila tidak ada aktivitas. Oleh sebab itu, aktivitas merupakan prinsip atau dasar yang sangat penting dalam interaksi belajar mengajar. Diedrich dalam Sardiman (2010) menggolongkan aktivitas siswa sebagai berikut. Visual Activities, Oral Activities, Listening Activites, Writing Activities, Drawing Activites, Motor Activities, Mental Activities dan Emotional Activities.

Hasil belajar matematika merupakan hasil akhir dari suatu proses belajar matematika sebagai perwujudan usaha yang telah dilakukan selama proses itu berlangsung. Sementara itu, pencapaian hasil belajar lebih sering dikaitkan dengan nilai perolehan siswa setelah proses belajar mengajar dan evaluasi yang diberikan. Sejalan dengan itu Nasution (1990) menyatakan bahwa hasil belajar adalah hasil 
dari interaksi belajar individu secara aktif dan pasif dengan lingkungannya. Sedangkan menurut Sukardi (1998) menyatakan bahwa hasil belajar adalah suatu bukti keberhasilan usaha belajar yang dicapai dalam kurun waktu tertentu. Seorang siswa yang belajar matematika, akan berusaha untuk dapat memahami materi pelajaran matematika yang telah dipelajarinya. Keberhasilan yang dicapai siswa dalam menguasai materi pelajaran yang telah dipelajarinya disebut hasil belajar Matematika (Melati, 2012). Dengan demikian dapat disimpulkan bahwa hasil belajar matematika adalah hasil yang dicapai oleh siswa setelah mengikuti suatu proses belajar matematika setelah dilakukan tes dan penilaiannya didasarkan pada standar tertentu.

Pada umumnya hasil pembelajaran matematika di Indonesia, termasuk pembelajaran trigonometri di SMA masih jauh dari memuaskan, bahkan kadang-kadang boleh dikatakan masih mengecewakan. Hal ini dapat dilihat dari hasil Nilai UAN dari tahun ke tahun untuk matematika, yang di dalamnya terdapat materi trigonometri termasuk dalam kategori "rendah". Menurut Hudojo (1988) belajar matematika akan berhasil bila proses belajarnya baik, yaitu melibatkan intelektual siswa secara optimal. Peristiwa belajar dikehendaki bisa tercapai jika faktor-faktor berikut ini dapat dikelola sebaik-baiknya. (1) Keberhasilan atau kegagalan dalam belajar tergantung kepada kemampuan dan kesiapan siswa untuk mengikuti kegiatan belajar matematika, sikap dan minat siswa terhadap matematika serta kondisi fisiologis dan psikologisnya. (2) Proses pembelajaran matematika dipengaruhi oleh bagaimana guru menguasai materi matematika dan menyampaikan materi matematika. Apabila guru tidak menguasai materi akan mengakibatkan rendahnya mutu pengajaran matematika, sedangkan jika guru tidak menguasai bagaimana cara menyampaikan materi dengan baik, akan mengakibatkan siswa kesulitan dalam memahami materi matematika, yang menyebabkan keengganan siswa untuk belajar yang pada akhirnya mengakibatkan proses belajar matematika tidak efektif. (3) Prasarana yang mapan dan lengkap akan meningkatkan kualitas belajar siswa. (4) Penilaian selain digunakan untuk melihat hasil belajar siswa, juga untuk melihat bagimana berlangsungnya interaksi antara pengajar dan siswa.

Hal ini juga terjadi di SMA Negeri 1 Kudus. Dalam pembelajaran di SMA 1 Kudus sejak tahun 1999 sampai sekarang, salah satu materi yang tidak disukai dan sulit di fahami oleh siswa adalah materi Trigonometri. Setiap kali siswa menjumpai soal yang berhubungan dengan trigonometri, maka mereka akan kesulitan dan tidak dapat menyelesaikannya, bahkan kadang-kadang mereka mengalami ketakutan yang berlebihan. Dari hasil pengamatan, hal ini disebabkan oleh banyak hal, di antaranya terlalu banyaknya rumus-rumus yang harus dikuasai oleh siswa sehingga mereka tidak hafal, kurangnya latihan soal-soal yang bervariasi, serta kurangnya pemahaman siswa dalam mempelajari trigonometri. Untuk mengatasi hal ini, maka diperlukan suatu metode pembelajaran yang bisa menambah aktivitas siswa untuk belajar, yang pada akhirnya dapat meningkatkan hasil belajar siswa itu sendiri. Salah satu metode pembelajaran yang dapat diterapkan adalah dengan metode tutor sebaya.

Tutor Sebaya merupakan salah satu metode atau pendekatan dalam pembelajaran kooperatif yang paling sederhana, dan merupakan pendekatan yang baik untuk guru yang baru memulai menerapkan model pembelajaran kooperatif dalam kelas. Nasution (1992) berpendapat bahwa bantuan tutor, adalah orang yang dapat membantu murid secara individual. Menurut Ischak dan Warji (1987) dan Hidayah (2013), tutor sebaya artinya siswa yang mengalami kesulitan belajar diberi bantuan oleh teman-teman mereka sekelas yang punya umur sebaya dengan dia.

Jadi tutor sebaya dapat diartikan seseorang atau beberapa orang siswa yang ditunjuk oleh guru sebagai pembantu guru dalam melakukan bimbingan terhadap kawan sekelas. Kelebihan dari pendekatan tutor sebaya ini adalah dapat melatih siswa dalam memecahkan masalah, mengatasi kesulitannya sendiri dan mampu membimbing diri sendiri. Selain itu karena tutor berasal dari teman sekelasnya maka siswa tidak merasa malu atau segan untuk bertanya apabila ada hal-hal yang kurang dimengerti dalam proses belajar mengajar 
(Anggorowati, 2011).

Berdasarkan latar belakang masalah di atas, maka permasalahan dalam penelitian ini adalah : (1) Apakah aktivitas belajar matematika siswa kelas X IPA 7 SMA 1 Kudus pada materi trigonometri dapat ditingkatkan dengan menggunakan metode tutor sebaya? (2) Apakah hasil belajar matematika siswa kelas XIPA 7 SMA 1 Kudus pada materi trigonometri dapat ditingkatkan dengan menggunakan metode tutor sebaya?

Tujuan dari penelitian ini berdasarkan latar belakang di atas adalah (1) untuk mengetahui bahwa aktivitas belajar matematika siswa kelas X IPA 7 SMA 1 Kudus pada materi trigonometri dapat ditingkatkan dengan menggunakan metode tutor sebaya dan (2) untuk mengetahui bahwa hasil belajar matematika siswa kelas X IPA 7 SMA 1 Kudus pada materi trigonometri dapat ditingkatkan dengan menggunakan metode tutor sebaya.

\section{METODE PENELITIAN}

Kegiatan pembelajaran diawali dengan memberikan pembekalan terhadap siswa yang akan ditunjuk sebagai tutor, agar dalam memberikan tutorial sesuai dengan tujuan pembelajaran yang diharapkan. Kemudian pada saat pembelajaran berlangsung siswa yang ditunjuk sebagai tutor akan memandu dan membantu teman-temannya untuk menyelesaikan tugas yang diberikan oleh guru. Dengan bimbingan dari sesama siswa diharapkan siswa menjadi lebih aktif dalam proses belajar. Apabila aktivitas siswa sudah terbentuk bagus dan dapat ditingkatkan akibatnya prestasi be- lajarnyapun akan meningkat pula.

Penelitian ini dilakukan di SMA Negeri

1 Kudus pada bulan Maret sampai Mei tahun 2013. Subyek penelitiannya adalah siswa kelas XIPA 7 tahun pelajaran 2012/2013. Penelitian ini adalah penelitian tindakan kelas yang terdiri atas 4 tahap, yaitu perencanaan, tindakan, observasi, dan refleksi. Rancangan penelitian tindakan kelas ini dilaksanakan dalam dua siklus. Sesuai dengan hakekat penelitian tindakan kelas, siklus kedua merupakan perbaikan siklus pertama. Untuk memperjelas prosedur pelaksanaan tindakan kelas dapat digambarkan sebagai berikut.

Untuk mengambil data digunakan metode dokumentasi, observasi (pengamatan) dan metode tes. Metode dokumentasi digunakan untuk mendapatkan data nama siswa dan data nilai siswa, sedangkan metode observasi digunakan untuk mengamati aktivitas siswa dalam proses pembelajaran. Hasil pengamatan yang dilakukan oleh guru pengamat dicatat pada lembar observasi yang sudah disediakan. Metode tes digunakan untuk mengambil data berkaitan dengan hasil belajar siswa. Tes yang digunakan dalam penelitian ini adalah tes berbentuk pilihan ganda.

Dalam penelitian ini validasi data untuk data aktivitas siswa dilakukan melalui triangulasi sumber yaitu kolaborasi dengan 2 teman sejawat. Sedangkan untuk data hasil belajar siswa, sebelum menyusun soal tes hasil belajar maka terlebih dahulu harus divalidasi dengan membuat kisi-kisi dari soal tersebut dengan tujuan agar terpenuhinya validitas teoretik, khususnya content validity. Di sam-

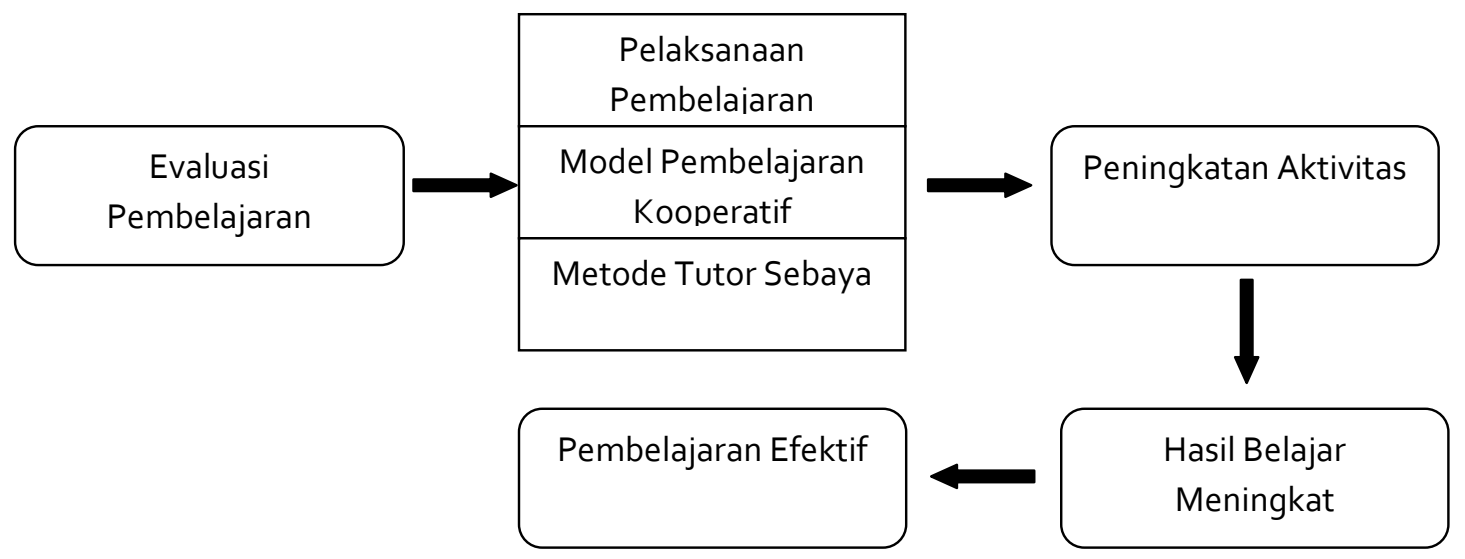

Gambar 1 Kerangka Berpikir 
ping itu juga agar indikator yang ingin dicapai bisa merata atau menyebar sesuai dengan kompetensi dasar yang harus dikuasai oleh setiap siswa pada materi trigonometri.

Analisis data dalam penelitian ini menggunakan analisis deskriptif komparatif yaitu dengan membandingkan hasil belajar siswa pada kondisi awal dengan siklus I, kondisi awal dengan siklus II, dan membandingkan hasil belajar siswa siklus I dan siklus II. Sedangkan untuk data aktivitas belajar siswa menggunakan analisis deskriptif kualitatif berdasarkan hasil observasi dan refleksi dari tiap-tiap siklusnya, yaitu dengan membandingkan aktivitas belajar siswa pada siklus I dan siklus II. Dengan demikian dari analisis tersebut maka dapat diketahui apakah metode pembelajaran tutor sebaya dapat meningkatkan aktivitas dan hasil belajar siswa pada materi trigonometri dari setiap siklus yang dilaksanakan.

\section{Indikator Kinerja}

Berdasarkan nilai KKM di SMA 1 Kudus kelas X IPA tahun pelajaran 2012/2013, yaitu sebesar 78, maka penelitian ini dikatakan berhasil apabila prestasi belajar siswa yang yang memenuhi nilai KKM (sebesar 78) lebih dari $75 \%$. Untuk keaktifan siswa indikator kinerjanya adalah keaktifan siswa masuk kategori Baik. Artinya penelitian ini dikatakan berhasil apabila skor keaktifan siswa 3 atau lebih.

\section{HASIL DAN PEMBAHASAN}

\section{Deskripsi Kondisi Awal}

Dari 11 rombel kelas $X$ parallel yang ada di SMA Negeri 1 Kudus tahun pelajaran 2012/2013, terdiri atas 8 kelas jurusan IPA dan 3 kelas jurusan IPS. Kelas X IPA-7 berjumlah 34 siswa yang terdiri dari 18 siswa putra dan 16 siswa putri memiliki aktivitas belajar dan nilai matematika yang rendah. Hal ini dapat dilihat dari aktivitas mereka pada waktu mengikuti pelajaran matematika di kelas dengan materi logika matematika. Dari 34 siswa di kelas X-IPA 7 ada sebanyak 2 siswa atau 6\% termasuk kategori sangat aktif, 11 siswa atau 32\% termasuk kategori cukup aktif, dan sisanya sebanyak 21 siswa atau 62\% siswa tergolong pasif. Rendahnya aktivitas belajar disebabkan oleh materi Logika yang kurang menarik serta metode yang dilakukan oleh guru mengajar disukai oleh siswa.

Hasil belajar matematika siswa kelas X-IPA 7 pada kondisi awal yaitu materi Logika kurang berarti bagi sebagian besar siswa, sehingga hasil belajar pada materi tersebut masih rendah. Hal ini dapat dilihat dari data bahwa siswa memperoleh nilai rata-rata 64,779 masih dibawah KKM yaitu sebesar 78 .

Nilai ulangan harian pada kondisi awal dapat dilihat pada Tabel berikut.

Tabel 1. Nilai Ulangan Harian pada Kondisi Awal

\begin{tabular}{ccc}
\hline No & Uraian & Nilai \\
\hline 1. & Nilai Terendah & 40 \\
2. & Nilai Tertinggi & 90 \\
3. & Nilai Rata-rata & 64,779 \\
4. & Rentang Nilai & 50 \\
\hline
\end{tabular}

\section{HASIL PENELITIAN}

\section{Siklus I}

\section{Perencanaan}

Pertama peneliti mempersiapkan perangkat pembelajaran yang akan digunakan, yaitu silabus pembelajaran, rencana pelaksanaan pembelajaran (RPP) dengan menggunakan metode Tutor sebaya dan Lembar Kerja Siswa (LKS). Selanjutnya peneliti mempersiapkan soal untuk mengukur kemampuan siswa pada materi trigonometri, dengan membuat kisi-kisi terlebih dahulu. Untuk siklus I materi hanya sampai pada Kompetensi Dasar 5.1. Selanjutnya peneliti mempersiapkan perangkat yang akan digunakan untuk mengamati aktivitas siswa, meliputi kisi-kisi pengamatan aktivitas siswa, indikator dan pedoman penskoran aktivitas siswa serta tabel untuk merekapitulasi hasil pengamatan yang dilakukan oleh pengamat (observer). Berikutnya peneliti mempersiapkan untuk proses pembelajarannya, yaitu menunjuk siswa sebagai tutor sebaya dalam pembelajaran. Siswa yang ditunjuk adalah siswa yang mempunyai kemampuan yang lebih dibandingkan dengan siswa-siswa yang lain. Hal ini dapat dilihat pada nilai-nilai ulangan sebelumnya serta kemampuan sehari-hari siswa dalam pembelajaran matematika. 


\section{Pelaksanaan}

Pada pertemuan pertama mempelajari tentang konsep perbandingan trigonometri pada segitiga siku-siku. Guru mengingatkan kembali tentang materi prasyarat yang diperlukan dalam pembelajaran trigonometri, yaitu teorema pytagoras. Selanjutnya guru memberikan motivasi tentang kegunaan dan manfaat trigonometri dalam kehidupan sehari-hari, dilanjutkan guru memberitahukan tujuan pembelajaran yang hendak dicapai.

Pada kegiatan inti pembelajaran, guru dengan bantuan bahan ajar presentasi (power point) menjelaskan tentang konsep perbandingan trigonometri pada segitiga sikusiku. Selanjutnya, guru membagi kelas dalam beberapa kelompok ( 6 kelompok) dengan masing-masing kelompok terdiri dari 5-6 siswa yang heterogen dimana masing-masing kelompok dipandu oleh satu siswa sebagai tutor sebaya. Setelah terbentuk kelompok, selanjutnya guru membagikan LKS 1 untuk didiskusikan oleh siswa dalam satu kelompok. Siswa yang sudah terbagi menjadi 6 kelompok aktif berdiskusi untuk menyelesaikan LKS yang sudah diberikan oleh guru. Tutor sebaya memberikan bimbingan pada saat ada siswa yang kurang memahami atau tidak dapat mengerti materi yang diajarkan oleh guru, sedangkan guru berkeliling untuk mengamati dan membimbing jika ada tutor sebaya tidak dapat menyelesaikan masalah dalam membimbing siswa-siswa lainnya. Setelah diskusi selesai, beberapa perwakilan kelompok maju untuk mempresentasikan hasil diskusi kelompoknya. Setelah materi dipahami dengan baik oleh siswa, guru memberikan beberapa soal latihan untuk dikerjakan siswa secara individu.

Di akhir pembelajaran, guru bersama siswa menyimpulkan materi pembelajaran pada pertemuan pertama, yaitu tentang perbandingan trigonometri pada segitiga sikusiku, dilanjutkan dengan memberikan PR untuk tugas di rumah. Pada pertemuan kedua dan ketiga proses pembelajaran hampir sama, hanya perbedaannya pada materi pokok yang diajarkan. Pada pertemuan kedua membahas tentang perbandingan trigonometri untuk sudut-sudut istimewa, dan pada pertemuan ketiga membahas tentang perbandingan trigonometri diberbagai kuadran. Setelah selesai memberikan tindakan pada proses pembelajaran, siswa diberi evaluasi dengan menggunakan tes ulangan harian yang sudah dipersiapkan.

\section{Observasi}

Dari hasil pengamatan aktivitas belajar siswa yang dilakukan oleh 2 guru pengamat pada siklus I menunjukkan bahwa skor ratarata keaktifan siswa adalah 3,25. Pada pertemuan pertama skor rata-rata keaktifan siswa adalah 2,81, pada pertemuan kedua adalah 3,24 dan pertemuan ke-3 adalah 3,70. Hal ini menunjukkan bahwa aktivitas belajar siswa pada siklus I masuk kategori baik. Data Nilai Ulangan Harian pada siklus I dapat dilihat pada Tabel 2 dan Tabel 3.

Tabel 2.Nilai Ulangan Harian Siklus I

\begin{tabular}{cc}
\hline URAIAN & NUH \\
\hline Nilai Terendah & 50 \\
Nilai Tertinggi & 100 \\
Nilai Rata-rata & 74,12 \\
Rentang Nilai & 40 \\
\hline
\end{tabular}

Tabel 3. Tabel Interval Nilai Ulangan Harian pada Siklus I

\begin{tabular}{ccc}
\hline Nilai & Frekuensi & Persentase \\
\hline $91-100$ & 2 & $5,88 \%$ \\
$81-90$ & 4 & $11,76 \%$ \\
$71-80$ & 15 & $44,12 \%$ \\
$61-70$ & 8 & $23,53 \%$ \\
$50-60$ & 5 & $14,71 \%$ \\
\hline
\end{tabular}

\section{Refleksi}

Secara umum proses pembelajaran dengan menggunakan metode tutor sebaya materi trigonometri pada siklus I ada peningkatan baik aktivitas siswa maupun hasil belajar siswa, namun peningkatannya masih rendah dan belum maksimal. Hal ini menurut peneliti ada beberapa hal yang menyebabkannya, yaitu: (1) peran tutor sebaya belum maksimal, beberapa siswa yang menjadi tutor masih agak kikuk dan penguasaan materinya belum menyakinkan sehingga beberapa tutor masih kurang percaya diri dalam memberikan bantuan ke teman-temannya; (2) beberapa siswa belum terbiasa dengan metode tutor sebaya, sehingga beberapa siswa masih belum aktif 
bertanya dan berdiskusi dengan tutornya. (3) pembagian Lembar Kerja Siswa (LKS) per kelompok hanya satu, sehingga beberapa siswa tampak kurang aktif berdiskusi karena merasa tugasnya sudah dikerjakan oleh siswa yang lain.

\section{Siklus II}

\section{Perencanaan}

Berdasarkan hasil refleksi pada siklus I maka pada siklus II diadakan pembekalan terhadap siswa yang dijadikan tutor. Pembekalan diadakan di luar jam pelajaran atau sepulang sekolah dan pada hari Minggu pagi. Pada pembekalan ini, siswa diajarkan semua materi yang akan didiskusikan pada siklus II, yaitu meliputi materi grafik fungsi trigonometri, persamaan trigonometri, identitas trigonometri dan aplikasi (penerapan) trigonometri pada kehidupan sehari-hari. Kemudian peneliti juga mempersiapkan LKS sebanyak jumlah siswa yang ada.

\section{Pelaksanaan}

Pelaksanaan pada siklus kedua hampir sama dengan siklus I. Letak perbedaanya pada materi pembelajaran, yaitu pertemuan pertama mempelajari tentang grafik fungsi trigonometri, pertemuan kedua membahas tentang persamaan trigonometri, pertemuan ketiga membahas tentang identitas trigonometri dan pada pertemuan terakhir membahas penerapan trigonometri dalam kehidupan sehari-hari.

\section{Observasi}

Hasil pengamatan aktivitas belajar siswa yang dilakukan oleh 2 guru pengamat pada siklus II menunjukkan bahwa skor ratarata keaktifan siswa adalah 3,82. Pada pertemuan pertama skor rata-rata keaktifan siswa adalah 3,54, pada pertemuan kedua adalah 3,80 dan pertemuan ke-3 adalah 4,12. Hal ini menunjukkan bahwa aktivitas belajar siswa pada siklus II masuk kategori baik. Data Nilai Ulangan Harian pada siklus II dapat dilihat pada Tabel 4 dan 5 berikut.
Tabel 4. Nilai Ulangan Harian Siklus II

\begin{tabular}{cc}
\hline Uraian & Nilai \\
\hline Nilai Terendah & 56 \\
Nilai Tertinggi & 100 \\
Nilai Rata-rata & 79,76 \\
Rentang Nilai & 44 \\
\hline
\end{tabular}

Tabel 5. Tabel Interval Nilai Ulangan Harian pada Siklus II

\begin{tabular}{ccc}
\hline Nilai & Frekuensi & Persentase \\
\hline $91-100$ & 4 & 11,76 \\
$81-90$ & 8 & 23,53 \\
$71-80$ & 18 & 52,94 \\
$61-70$ & 2 & 5,88 \\
$51-60$ & 2 & 5,88 \\
\hline
\end{tabular}

Refleksi

Aktivitas siswa pada siklus dalam proses pembelajaran sudah mengalami peningkatan, hal ini terlihat dari tabel ada sebanyak 22 siswa atau $65,71 \%$ keaktifannya masuk dalam kategori baik, dan sebanyak 12 orang atau 35, 29 $\%$ masuk dalam kategori sangat baik.Aktivitas belajar sudah baik dengan skor 3,82. Jadi ada peningkatan aktivitas dari siklus I yang skornya 3,25 menjadi 3,82, meningkat sebesar $18 \%$. Sedangkan hasil belajar siswa nilai rata-rata juga mengalami peningkatan dari semula 74,12 menjadi 79, 82. Pada siklus I siswa yang mendapat nilai $\geq 78$ hanya 13 siswa atau $38,2 \%$, dan pada siklus II ada sebanyak 26 siswa atau $76,47 \%$, sehingga sudah mencapai indicator penelitian.

\section{PEMBAHASAN}

\section{Aktivitas Belajar Siswa}

Berdasarkan data hasil penelitian aktivitas siswa, diperoleh data pada siklus I skor minimal 2,48 , skor maksimal 4,12 dan skor rata-rata aktivitas siswa sebesar 3,25. Sedangkan hasil pengamatan aktivitas siswa pada siklus II diperoleh data skor minimal 3,32, skor maksimal 4,39 dan skor rata-rata dari aktivitas siswa sebesar 3,82. Hal ini dapat disajikan dalam gambar Gambar 3 berikut. 


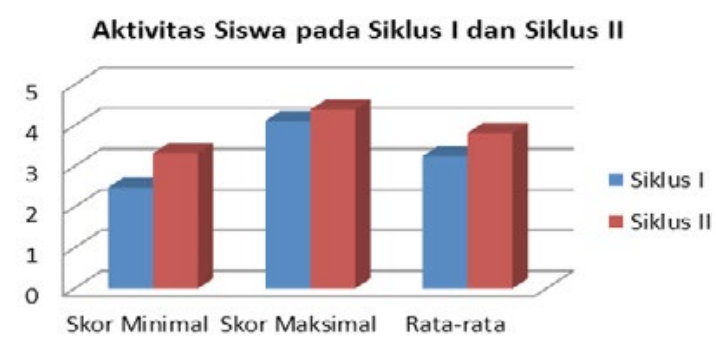

Gambar 3. Data Aktivitas Siswa pada Siklus I dan Siklus II

Berdasarkan grafik di atas dapat dilihat bahwa ada peningkatan aktivitas belajar siswa dari siklus I ke siklus II. Adanya peningkatan aktivitas belajar siswa pada siklus II dikarenakan siswa sudah terbiasa dengan metode tutor sebaya yang digunakan, mereka dengan santai tanpa ada tekanan bertanya dengan tutor mereka, saling berdiskusi membahas materi tanpa ada rasa sungkan. Selain itu kemampuan tutor sebaya yang sudah lebih baik dibandingkan pada siklus I juga ikut mempengaruhi. Dengan diberi pembekalan di luar jam sekolah, para tutor menjadi lebih menguasai materi dengan baik, sehingga percaya diri mereka pada saat menjelaskan kepada teman-teman mereka yang lain menjadi semakin baik, akibatnya tingkat pemahaman siswa terhadap materi trigonometri semakin baik pula. Dengan kemampuan pemahaman semakin baik siswa menjadi senang mempelajari matematika, sehingga aktivitas belajar mereka juga meningkat.

\section{Hasil Belajar Siswa}

Hasil tes hasil belajar siswa menunjukkan bahwa pada kondisi awal diperoleh nilai rata-rata hasil belajarnya 64,78 , pada siklus I nilai tes rata-rata sebesar 74,12 dan pada tes hasil tes belajar siswa pada siklus II diperoleh nilai ratarata sebesar 79,76 . Hal ini dapat disajikan dalam gambar grafik berikut.

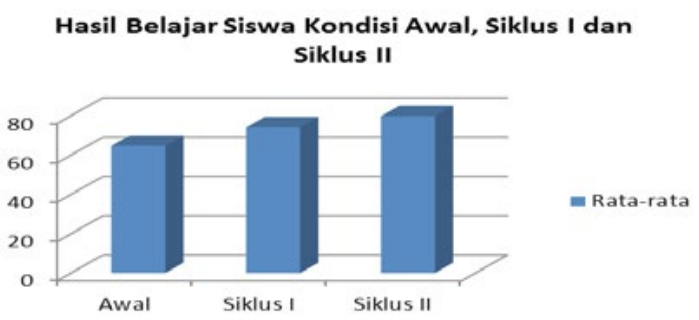

Gambar 4. Hasil Belajar Siswa pada Kondisi Awal, Siklus I dan II

Berdasarkan grafik di atas terlihat bahwa ada peningkatan hasil belajar siswa dari kondisi awal, siklus I dan siklus II. Nilai ratarata hasil belajar pada kondisi awal adalah 64,78 , pada siklus I sebesar 74,12, sedangkan pada siklus II sebesar 79,76 . Hal ini berarti ada peningkatan hasil belajar siswa dari kondisi awal sampai siklus II sebesar 14,98 atau meningkat sebesar $23,12 \%$.

Untuk tingkat ketuntasan belajar siswa dengan KKM 78, diperoleh data dari 34 jumlah siswa kelas XIPA 7, yang memperoleh nilai lebih dari atau sama dengan 78 pada kondisi awal ada sebanyak 5 siswa atau $14,7 \%$, pada siklus I ada sebanyak 13 siswa atau 38,24\% dan pada siklus II ada sebanyak 26 siswa atau $76,47 \%$. Hal ini dapat disajikan dalam gambar grafik seperti Gambar 5.

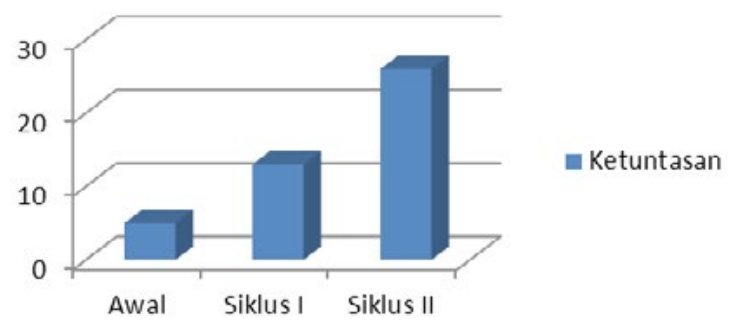

Gambar 5. Ketuntasan Belajar Siswa pada Kondisi Awal, Siklus I dan II

Dari gambar di atas dapat dilihat bahwa ada peningkatan jumlah siswa yang mencapai ketuntasan belajar. Sesuai dengan indikator penelitian bahwa penelitian ini dikatakan berhasil apabila ketuntasan mencapai lebih dari $75 \%$, sehingga karena pada siklus II sudah mencapai ketuntasan, maka penelitian ini bisa dikatakan telah berhasil meningkatkan hasil belajar siswa.

\section{PENUTUP}

\section{Simpulan}

Berdasarkan hasil penelitian dan pembahasan di atas maka dapat disimpulkan: (1) aktivitas belajar matematika siswa kelas X IPA 7 SMA 1 Kudus pada materi trigonometri dapat ditingkatkan dengan menggunakan metode tu- 
tor sebaya yaitu sebesar $17,54 \%$ dan (2) hasil belajar matematika siswa kelas X IPA 7 SMA 1 Kudus pada materi trigonometri dapat ditingkatkan dengan menggunakan metode tutor sebaya, yaitu sebesar $23,12 \%$.

\section{Saran}

Berdasarkan hasil penelitian di atas, maka penulis memberi saran : (1) Metode tutor sebaya ini bisa diterapkan pada materi-materi yang lain, karena sudah terbukti efektif meningkatkan aktivitas dan hasil belajar siswa pada materi trigonometri. (2) Agar guru dapat lebih meningkatkan kompetensi profesional guru dengan mengembangkan proses pembelajaran yang inovatif.

\section{DAFTAR PUSTAKA}

Anggorowati, N. P. (2011). Penerapan Model Pembelajaran Tutor Sebaya Pada Mata Pelajaran Sosiologi. Komunitas: International Journal Of Indone- sian Society And Culture, 3(1).

Hidayah, M. (2013). Pengoptimalan Keterampilan Membaca Bahasa Arab Dengan Model Pembelajaran Tutor Sebaya di Kelas VII H MTs Negeri Kendal Tahun 2012/2013. Lisanul'Arab: Journal of Arabic Learning and Teaching, 2(1).

Hudojo, H. (1988). Mengajar Belajar Matematika. Jakarta, Depdikbud, Dirjen Dikti PPLPTK

Ishak dan Warji. (1987). Program Remedial dalam Proses Belajar Mengajar. Yogyakarta. Liberty.

Melati, H. A. (2012). Meningkatkan Aktivitas dan Hasil Belajar Siswa SMAN 1 Sungai Ambawang Melalui Pembelajaran Model Advance Organizer Berlatar Numbered Heads Together (NHT) Pada Materi Kelarutan dan Hasil Kali Kelarutan (619630)-HA Melati. Jurnal Visi Ilmu Pendidikan (JVIP), 6(3).

Nasution, A.H. (1990). Landasan Matematika. Jakarta : Bharata Karya Aksara.

Nasution. (1992). Tekhnologi Pendidikan. Bandung. Jemmars.

Sardiman, A.M. (2010). Interaksi dan Motivasi Belajar Mengajar. Jakarta: PT Raja Grafindo Persada.

Sukardi. (1998). Interaksi dan Motivasi Belajar Mengajar. Jakarta : CV Rajawali. 